\title{
PENGEMBANGAN PENGUKURAN KETERAMPILAN SOSIAL SISWA SEKOLAH DASAR INKLUSIF BERBASIS DIVERSITY AWARENESS
}

\author{
Tin Suharmini, Purwandari, Aini Mahabbati, dan Heri Purwanto \\ Universitas Negeri Yogyakarta \\ Email: aini@uny.ac.id
}

\begin{abstract}
Abstrak
Penelitian ini bertujuan untuk mengembangkan konstrak skala pengukuran keterampilan sosial siswa sekolah dasar inklusif berbasis diversity awareness. Langkah penelitian adalah eksplorasi konstrak keterampilan sosial melalui kajian pustaka dan FGD dan mengonstruksi aspek dan indikator untuk menjadi rancangan skala perilaku Likert. Subjek penelitian adalah 15 guru kelas dari SD inkusif. Hasil penelitian menunjukkan aspek keterampilan sosial berdasarkan diversity awareness yang berhasil dirumuskan tujuh (7) aspek, meliputi kemampuan empati $(32,4 \%)$, komunikasi dan interaksi sosial $(28,9 \%)$, mengendalikan agresi $(10,8 \%)$, sikap terbuka $(8,8 \%)$, perilaku membantu $(8,3 \%)$, kemampuan memahami diri $(6,9 \%)$, dan perilaku mau belajar (3,9\%). Rancangan instrumen pengukuran skala keterampilan sosial siswa SD inklusif berbasis diversity awareness terdiri dari indikator-indikator yang ditetapkan berdasarkan proporsi persentase kemunculan masing-masing aspek. Aspek kemampuan empati memiliki 15 indikator, komunikasi dan interaksi sosial 13 indikator, mengendalikan agresi 5 indikator, sikap terbuka 4 indikator, perilaku membantu 4 indikator, memahami diri 3 indikator, dan perilaku mau belajar 2 indikator. Total indikator berjumlah 46 yang menjadi item pada alat ukur yang dihasilkan.
\end{abstract}

Kata Kunci: diversity awareness, keterampilan sosial, pengukuran perilaku.

\section{THE DEVELOPMENT OF SOCIAL SKILLS MEASUREMENT OF PRIMARY SCHOOL INCLUSIVE STUDENT BASED ON DIVERSITY AWARENESS}

\begin{abstract}
This research aimed to develop the constuction of social skills measurement scale for inclusive primary school students based on diversity awareness. The phases of this research were the exploration of the social skills construction through the literature study and FGD, and constructed the aspects and indicators to be designed as Likert scale behavior. The subjects were 15 teachers from elementary inclusive schools. The results formulated seven (7) aspects of social skills based on diversity awareness, including the ability of empathy (32.4\%), communication and social interaction (28.9\%), controlling aggression (10.8\%), openness (8.8\%), helping behavior (8.3\%), the ability to understand themselves (6.9\%), and willing to learn (3.9\%). The draft of instrument consists of indicators defined by the proportion of the percentage of each of these aspects. Aspects capacity for empathy has 15 indicators, communication and social interaction has 13 indicators, controlling aggression has five indicators, four indicators for openness, behavior helped for four indicators, three indicators for understanding themselves, and willingness to learn has two indicators. Total indicators are 46 which become the items on the resulting measurement tool.
\end{abstract}

Keywords: diversity awareness, social skills, behavior measurement.

\section{PENDAHULUAN}

Keterampilan sosial merupakan istilah bagi kemampuan untuk berhubungan dengan lingkungan sosial secara sesuai. Samanci (2010:150) menyebut keterampilan sosial sebagai kemampuan yang dibutuhkan untuk menjalin interaksi sosial dan untuk mampu 
beradaptasi terhadap harapan lingkungan. Keterampilan sosial tampak pada sikap dan perilaku keseharian, seperti kemampuan berkomunikasi; menyesuaikan diri, keterlibatan dalam kelompok; mengatasi masalah; dan mengembangkan potensi diri dalam konteks lingkungan. Keterampilan sosial yang baik dibutuhkan bagi siswa di sekolah. Keterampilan sosial di sekolah akan mendukung interaksi dan kolaborasi siswa dengan teman dan guru (MazurikCharles \& Stefanou, 2010:162). Selain itu, keterampilan sosial di sekolah juga mendukung kemampuan problem solving siswa, serta berempati terhadap orang lain (Dereli, 2009:1420). Oleh karena itu, Shepherd (2010:43) menyebut keterampilan sosial sebagai kemampuan atau modal penting bagi anak untuk mencapai kesiapan emosi dan perilaku di sekolah. Adapun fungsi keterampilan sosial di sekolah adalah untuk melakukan hubungan sosial dengan guru dan teman, serta agar dapat menyesuaikan diri dengan aktivitas dan tuntutan pembelajaran.

Khusus pada keterampilan sosial di sekolah, Walker dan Mc.Connell (Merrell, 2001:14) menyebutkan tiga kategori perilaku yang menjadi indikator keterampilan sosial yang mendukung kegiatan pembelajaran pada anak usia sekolah dasar. Pertama yaitu: TeacherPreferred Social Behavior meliputi perilaku sosial dasar pendukung interaksi sosial, meliputi perilaku kontak dan komunikasi, simpati dan empati, kompromi dan kerjasama; serta perilaku mengatasi masalah, berupa merespon gangguan dan masalah, dan mengatasi dorongan perilaku agresi. Kedua adalah Peer-Preferred Social Behavior, yakni interaksi berteman di luar pembelajaran meliputi penerimaan teman, perilaku interaksi berteman, adaptasi, perilaku membantu, inisiatif, dan bakat positif yang ditunjukkan. Ketiga adalah School Adjustment Behavior atau perilaku yang menunjukkan penyesuaian diri terhadap aktivitas pembelajaran, meliputi kemampuan manajemen waktu, mengikuti arahan pembelajaran, kemampuan berkarya, dan respon terhadap pembelajaran.

Dinamika dan masalah keterampilan sosial pada seting sekolah menjadi persoalan yang menarik untuk dikaji, terutama pada sekolah yang memiliki siswa dengan latar belakang yang beragam. Keberagaman anak kerap ditemui di sekolah reguler dan semakin nyata terlihat pada sekolah inklusi. Sekolah inklusi menerima siswa dengan berbagai kondisi yang beragam pada aspek keadaan sosial, ekonomi, budaya, kemampuan akademik, dan utamanya adalah aspek kebutuhan khusus siswa. Keterampilan sosial siswa di sekolah inklusif seringkali menjadi persoalan sekaligus menjadi tantangan untuk disikapi secara positif. Problem keterampilan sosial yang dialami siswa di sekolah inklusif tampak pada berbagai perilaku dalam pembelajaran maupun non pembelajaran. Penelitian Purwandari, Pujaningsih \& Mahabbati (2014) menunjukkan bahwa anak yang SD inklusi yang mengalami masalah keterampilan sosial cenderung bermasalah perilaku. Hasil penelitian di sembilan sekolah inklusif di Kodya Yogya tersebut menemukan 77 siswa dengan masalah perilaku, 55 laki- laki dan 22 perempuan. Berbagai jenis kasus masalah perilaku yang sering dijumpai pada 77 siswa tersebut yakni tidak menyelesaikan dan enggan mengerjakan tugas $(77,8 \%$ dan $55,6 \%)$, berbicara dan atau berteriak di kelas $(55,6 \%)$, memukul teman $(48 \%)$, tidak masuk sekolah tanpa ijin (44\%), mengambil benda milik orang lain $(48 \%)$, dan perilaku provokatif, membuat keributan, marah, dan melukai teman $(11 \%)$. Seorang siswa bisa melakukan lebih dari satu jenis perilaku bermasalah. Marlina (2006:34) menemukan salah satu kasus yang muncul dari rendahnya keterampilan sosial di sekolah inklusif adalah penerimaan teman yang rendah terhadap anak berkesulitan belajar, sehingga mereka cenderung dijauhi oleh teman sebaya.

Lane, dkk menyatakan bahwa keterampilan sosial yang rendah 
menyebabkan anak sering mengalami penolakan dari teman bahkan guru, mengalami kegagalan di sekolah, dan miskin keterlibatan sosial (Shepherd, 2010:56). Penelitian Aini Mahabbati (2012) menunjukkan bahwa anak dengan gangguan perilaku yang rendah keterampilan sosial cenderung hanya berteman dengan sesama teman yang bermasalah perilaku, ditolak dan diejek oleh anak sebaya, dilabel negatif oleh lingkungan tempat tinggal, dan sulit melakukan kontak sosial yang positif dengan guru, orang dewasa lain, dan teman-temannya. Masalah akademik dan sosial mereka, menurut Odgers, dkk., terjadi karena perilaku adaptasi terhadap tugas akademik yang buruk dan atau karena ditolak lingkungan sekolah (Swift, dkk., 2009:339).

Sekolah inklusi pada umumnya telah melakukan upaya untuk mengatasi rendahnya keterampilan sosial siswanya. Penelitian Purwandari, Pujaningsih \& Mahabbati (2014) menunjukkan bahwa meskipun sekolah belum memiliki program yang tersistem dan prosedural untuk meningkatkan keterampilan sosial anak, namun sudah ada upaya untuk melatihkan keterampilan sosial siswa. Upaya yang sering dilakukan di sekolah adalah keterampilan sosial disampaikan oleh guru kelas pada setiap mata pelajaran yang diampu dan diberitahukan atau diajarkan langsung dalam aktivitas seharihari di lingkungan sekolah.

Keberagaman yang ada di sekolah inklusif menjadi tantangan tersendiri bagi pengembangan keterampilan sosial siswa. Bagi siswa dengan kebutuhan khusus, sekolah dapat menjadi tempat yang baik untuk mengembangkan kemampuan komunikasi, adaptasi, kepercayaan diri, keterlibatan sosial, berteman, dan mengatasi masalah. Adapun bagi siswa lainnya, Vaidya \& Zaslavsky (2000:14) mengemukakan bahwa keberadaan siswa berkebutuhan khusus di kelas reguler dapat mengembangkan keterampilan sosial bagi siswa lainnya, berupa kemampuan berteman; pemahaman tentang keragaman; kepedulian; kemampuan sosial; dan menurunkan kecemasan anak terhadap perbedaan.

Salah satu faktor penting dalam kajian mengenai pengembangan keterampilan sosial siswa di sekolah inklusif adalah diversity awareness (kesadaran akan keberagaman). Diversity awareness adalah kesadaran akan adanya keberagaman di sekitar yang aspeknya adalah pemahaman mengenai keberagaman tersebut, sikap menghargai, pengenalan akan nilai-nilai yang berbeda, dan pengetahuan mengenai dampak keberagaman (Brown \& Brown, 2004:56). Diversity awareness di sekolah biasanya tampak pada sikap menghargai, komunikasi yang akomodatif, dukungan sosial, memberi kesempatan partisipasi, dan berinteraksi secara terbuka dan tidak memilih teman. Berbagai aspek dalam diversity awareness tersebut sangat erat kaitannya dengan keterampilan sosial.

Favazza dkk. (2000:491) menyatakan bahwa penerimaan terhadap keberadaan siswa berkebutuhan khusus tidak dapat terjadi begitu saja. Dukungan dan pengkondisian diperlukan untuk mengajak seluruh siswa mengembangkan perilaku yang menghargai perbedaan. Penolakan teman sebaya kepada ABK banyak ditemui ketika tidak ada dorongan untuk menerima mereka (Favazza, dkk., 2000:491). Layanan terhadap keberagaman anak merupakan cerminan kualitas pendidikan. Selama ini di sekolah inklusi, guru juga semakin menyadari bahwa layanan ditujukan ke semua anak, tidak terbatas pada anak berkebutuhan khusus (Kluth, 2003:67). Mempertegas hal tersebut dalam pernyataannya bahwa pendidikan yang berkualitas dapat tercermin dari pemberian program yang menjangkau semua anak supaya mereka dapat berkembang secara intelektual dan sosial secara maksimal, dan bukan pemberian program yang sama untuk semua anak.

Berdasarkan latar belakang tersebut di atas, maka penelitian ini bertujuan untuk mengembangkan instrumen pengukuran 
keterampilan sosial siswa sekolah dasar inklusif yang berbasis diversity awareness. Tujuan khususnya adalah menemukan aspek keterampilan sosial siswa SD berbasis diversity awareness dan bagaimana pengembangan instrumen pengukurannya atau skalanya. Pengembangan instrumen pengukuran skala keterampilan sosial diperlukan untuk menjadi alat ukur capaian keterampilan sosial siswa yang dapat menjadi pedoman perencanaan dan evaluasi program pengembangan keterampilan sosial yang dilaksanakan di sekolah. Adanya instrumen pengukuran keterampilan sosial akan menjadi tolok ukur yang jelas pada kajian keberhasilan dan pengembangan keterampilan sosial siswa di sekolah inklusif.

\section{METODE}

\section{Definisi Operasional Variabel Penelitian}

Penelitian ini akan mengembangkan skala pengukuran keterampilan sosial siswa sekolah dasar inklusif berbasis diversity awareness. Oleh karena itu, keterampilan sosial berbasis diversity awareness merupakan variabel penelitian. Definisi operasionalnya adalah keterampilan yang berupa sikap atau perilaku yang membantu siswa untuk dapat berinteraksi di lingkungan sekolah dengan guru, seluruh teman, dan warga sekolah lainnya dengan situasi yang beragam.

\section{Tempat Penelitian}

Pengambilan data dalam penelitian ini menggunakan cara FGD. FGD dilaksanakan sebanyak dua kali dengan peserta berbeda yang bertempat Laboratorium Jurusan PLB FIP UNY pada tanggal 13 Oktober 2016. Grup 1 bertempat di Ruang Kelas Barat, dan Grup 2 bertempat di Ruang Kelas Tengah.

\section{Subjek Penelitian}

Subjek penelitian dalam penelitian ini berperan sebagai sumber utama yang memiliki data mengenai variabel yang akan diteliti. Subjek penelitian ini adalah guru kelas sekolah inklusi negeri dan swasta. Kriteria guru yang dilibatkan adalah guru kelas yang memiliki pengalaman mengajar anak berkebutuhan khusus selama minimal dua (2) tahun. Subjek penelitian pada FGD pertama berjumlah tujuh (7) orang guru dari lima (5) SD negeri dan dua (2) SD swasta. Seluruh sekolah berasal dari SD yang berbeda. Berikut adalah data guru subjek dan asal sekolah pada FGD Grup 1.

\section{Tabel 1. Data Guru dan Asal Sekolah pada FGD Grup 1}

\begin{tabular}{llll}
\hline No & $\begin{array}{l}\text { Nama } \\
\text { Guru }\end{array}$ & $\begin{array}{l}\text { Jenis } \\
\text { Kelamin }\end{array}$ & Asal Sekolah \\
\hline 1. & YUS & Pr & SD N Balirejo \\
2. & ANA & Pr & SD N Pakel \\
3. & IND & Pr & SD N Giwangan \\
4. & LUN & Pr & SD N Bangunrejo 2 \\
5. & SAN & Lk & SD N Karanganyar \\
6. & ROB & Lk & SD Taman Muda IP (swasta) \\
7. & FAT & Pr & SD Intis School (swasta) \\
\hline
\end{tabular}

Adapun pada FGD Grup 2, peserta berjumlah delapan (8) guru. Peserta tersebut berasal dari tujuh (7) SD negeri dan satu (1) SD swasta. Dua orang peserta berasal dari SD yang sama. Berikut adalah data subjek dan asal sekolah dari FGD Grup 2.

Tabel 2. Data Guru dan Asal Sekolah pada FGD Grup 2

\begin{tabular}{llll}
\hline No & $\begin{array}{l}\text { Nama } \\
\text { Guru }\end{array}$ & $\begin{array}{l}\text { Jenis } \\
\text { Kelamin }\end{array}$ & Asal Sekolah \\
\hline 1. & HER & Pr & SD N Giwangan \\
2. & EDY & Lk & SD N Pilahan \\
3. & SRI & Pr & SD N Pilahan \\
4. & RIA & Pr & SD N Pakel \\
5. & PUR & Lk & SD N Karanganyar \\
6. & DWI & Pr & SD N Bangunrejo 2 \\
7. & DHE' & Pr & SD N Balirejo \\
8. & AST & Pr & SD Taman Muda IP \\
& & & (swasta)
\end{tabular}

\section{Skenario Penelitian}

Penelitian ini bertujuan untuk mengkonstruksi skala keterampilan sosial berdasarkan diversity awareness untuk 
siswa sekolah dasar. Proses penelitian ini melalui dua skenario, yakni eksplorasi konstrak skala dan kontruksi skala. Bagan berikut ini menjelaskan alur skenario penelitian.

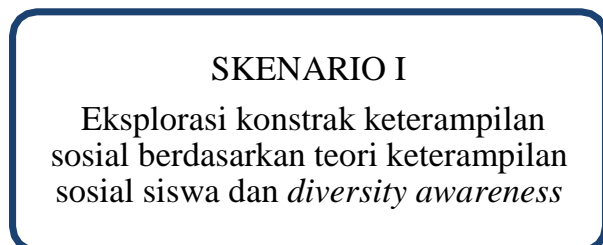

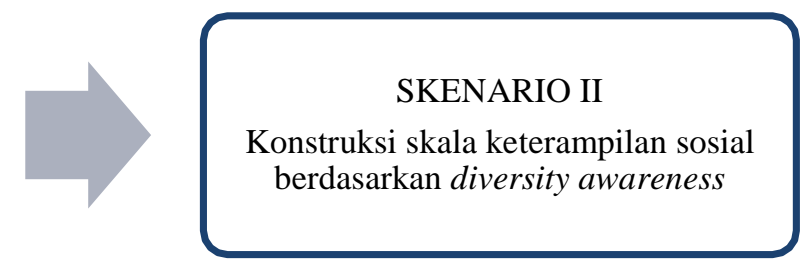

\section{Gambar 1. Skenario Penelitian}

a. Skenario Pertama: Eksplorasi

Konstrak Keterampilan Sosial

Eksplorasi konstrak keterampilan sosial dilakukan dengan pengkajian sumber pustaka dan pengalaman empirik mengenai keterampilan sosial pada siswa sekolah dasar dan dipadankan dengan sumber pustaka mengenai diversity awareness di sekolah inklusif. berikut :

Tahapannya adalah sebagai

1) Penyusunan Instrument Eksplorasi

\section{Keterampilan Sosial}

a) Mengkaji dan merumuskan aspek-aspek keterampilan sosial siswa SD berdasarkan kajian teori yang ada.

b) Mengadakan FGD untuk menemukan aspek-aspek keterampilan sosial siswa SD berdasarkan kebutuhan pengembangan diversity awareness yang bersumber dari pengalaman guru yang mengajar di sekolah inklusif. FGD dilakukan dua kali dengan peserta yang berbeda untuk dapat mengelaborasi secara komprehensif aspek-aspek keterampilan sosial. Peserta FGD adalah guru dari sekolah inklusif negeri dan swasta yang disebut sebagai subjek penelitian. Peserta FGD pertama berbeda dengan peserta FGD kedua. c) Merumuskan kata kunci-kata kunci keterampilan sosial dari hasil FGD.

2) Analisis Data dengan Kategorisasi dan Koding Respon

Metode yang analisis data dengan kategorisasi dan koding ini merupakan metode kualitatif. Data berupa kata-kata yang diperoleh dari responden mengenai keterampilan sosial pada FGD dirumuskan menjadi kata kunci - kata kunci, atau disebut dengan kategori. Kemudian kategori yang ditemukan dipilah dengan koding.

b. Skenario Kedua : Konstruksi Skala Keterampilan Sosial

Skenario kedua meliputi konstruksi skala pengukuran keterampilan sosial siswa SD inklusi berbasis diversity awareness dari hasil koding FGD yang dielaborasi dengan hasil kajian mengenai keterampilan sosial. Aspek-aspek keterampilan sosial yang ditemukan kemudian dirumuskan dalam beberapa indikator perilaku. Skala yang dirumuskan berupa skala pengukuran model Likert. Skala yang digunakan pada instrumen adalah: 1 untuk perilaku yang tidak pernah muncul; 2 untuk perilaku yang jarang muncul; 3 untuk perilaku yang kadang-kadang muncul; dan 4 untuk perilaku yang tidak pernah muncul. Prosedur konstruksi skala merujuk pada konstruksi skala psikologi yang dirumuskan oleh Saifuddin Azwar (2008:43), yakni: 
a. Stimulusnya berupa pertanyaan atau pernyataan yang tidak langsung mengungkap atribut yang hendak diukur, melainkan mengungkap indikator perilaku dari atribut yang hendak diukur.

b. Skala psikologi selalu berisi banyak aitem. Jawaban subyek terhadap satu aitem baru merupakan sebagian dari banyak indikasi mengenai atribut yang hendak diukur, sedangkan kesimpulan akhir sebagai suatu diagnosis baru dapat dicapai bila semua aitem telah direspon.

c. Respon subyek tidak diklasifikasikan sebagai jawaban benar atau salah. Semua jawaban dapat diterima sepanjang diberikan secara jujur dan sungguh-sungguh. Hanya saja jawaban yang berbeda akan diinterpretasikan berbeda pula.

Skala yang akan dihasilkan dalam penelitian ini adalah skala psikologi yang berisi sikap atau perilaku yang menggambarkan keterampilan sosial siswa SD berdasarkan diversity awareness. Teori yang dirujuk adalah teori keterampilan sosial siswa SD yang menggambarkan penyesuaian sosial dan tugas belajar atau social competence and school adjustment dari Walker \& Mc.Connel (Merrel, 2001:14).

\section{HASIL DAN PEMBAHASAN}

\section{Dinamika dan Hasil Focus Group Discussion}

FGD dibagi menjadi dua kelompok dengan peserta yang berbeda. Grup 1 bertempat di ruang kelas barat Laboratorium PLB FIP dan Grup 2 bertempat di ruang kelas tengah Laboratorium PLB FIP. FGD dilaksanakan pada tanggal 13 Oktober 2016 jam 13.00 sampai jam 15.30. Peserta adalah guru kelas di sekolah inklusi area Kota Yogyakarta yang telah bertugas mengajar minimal 2 tahun. Grup 1 diikuti oleh 7 peserta dan Grup 2 diikuti oleh 8 peserta.

Setiap Grup FGD diikuti oleh satu orang fasilitator, seorang pembantu fasilitator merangkap dokumenter, dan seorang pencatat. Prosedur FGD meliputi pembukaan dan penyampaian maksud dan tujuan FGD oleh fasilitator, kemudian disambung dengan sesi diskusi. Sesi diskusi dimulai dengan menyampaikan apersepsi mengenai keadaan di suatu sekolah dasar yang beragam dengan berbagai kasus interaksi sosial antar siswa dengan siswa, siswa dengan guru, dan sebagainya. Apersepsi ditutup dengan pertanyaan mengenai istilah bagi kemampuan yang perlu dikembangkan siswa berdasarkan kasus pada apersepsi.

Hasil FGD dari dua grup tersebut menunjukkan bahwa kemampuan yang dibutuhkan untuk berinteraksi dalam kondisi yang beragam adalah kemampuan memahami diri, kemampuan menerima dan menghargai kekurangan dan kelebihan teman, kemampuan berbagi, kemampuan berempati, kemampuan kerjasama, kemampuan saling menolong, perilaku terbuka untuk berteman, dan kemampuan bertanggung jawab.

Setelah sesi apersepsi dan pembahasan selesai, fasilitator menyampaikan judul dan tujuan penelitian dan peran para subjek penelitian. Kemudian, fasilitator menyampaikan pengertian keterampilan sosial anak SD sesuai dengan teori dari Gresham (Shepherd, 2010:63), Maag (2006:15), dan Samanci (2010:150).

Berdasarkan teori-teori tersebut fasilitator mengarahkan peserta untuk menyusun istilah sendiri mengenai keterampilan sosial. Berdasarkan pembahasan di dua grup, disimpulkan bahwa keterampilan sosial merupakan istilah yang menggambarkan kemampuan untuk mengenal lingkungannya, berinteraksi dan beradaptasi dengan lingkungan, kemampuan berkomunikasi verbal dan non verbal, kemampuan bekerjasama, kemampuan menerima kondisi yang berbeda, kemampuan membantu dan mendukung orang lain, dan kemampuan saling memahami.

Pembahasan berikutnya adalah keterampilan sosial yang dibutuhkan di sekolah inklusi yang memiliki siswa yang 
beragam. Menurut pengalaman subjek dari dua grup, teridentifikasi keterampilan sosial yang dibutuhkan di sekolah, yakni kemampuan menolong teman, memahami dan menghargai keadaan dan kemampuan teman, bekerjasama dengan seluruh teman, kemampuan memperhatikan teman dan guru, kemampuan mengekspresikan diri dengan sesuai dan kepercayaan diri, dan kemampuan mengendalikan diri.

Hasil FGD juga menunjukkan kondisi keberagaman di sekolah dasar. Keberagaman tersebut adalah perbedaan tingkat ekonomi, yakni dari ekonomi menengah ke atas sampai menengah ke bawah. Namun ada satu SD swasta yang menyatakan tidak terlalu beragam kondisi ekonominya. Keberagaman lain adalah keberagaman sosial yang umumnya dicermati dari lingkungan tempat tinggal keluarga, latar belakang pendidikan orangtua, pola asuh, dan sebagainya. Keberagaman lain adalah kemampuan belajar dan kebutuhan khusus siswa, yakni lamban belajar, kesulitan belajar, hambatan fisik, hambatan sensori (tunarungu dan tunanetra), gangguan emosi dan perilaku, hambatan komunikasi (autism), anak berbakat, dan sebagainya.

FGD juga membahas mengenai situasi di sekolah yang membutuhkan keterampilan sosial. Dua grup mengindentifikasi situasi-situasi tersebut, yakni ketika kegiatan belajar mengajar, meliputi diskusi kelas, kerja kelompok, praktik, unjuk kerja, kegiatan pembelajaran; saat istirahat; saat belajar di luar kelas; saat teman sakit; acara sekolah; dan saat pulang sekolah.

Pembahasan berikutnya adalah perilaku yang menujukkan rendahnya keterampilan sosial siswa di sekolah. Hasil FGD dua grup menyebutkan beberapa perilaku yang menunjukkan rendahnya keterampilan sosial, yakni tidak sopan terhadap orang dewasa; berkata kasar dan jorok; menentang, membantah, atau menolak instruksi guru; tidak merasa salah berbuat salah; menarik diri; pendiam atau sulit memulai komunikasi; tidak menjaga kebersihan; sering dihukum guru. Perilaku rendahnya keterampilan sosial terutama yang berhubungan dengan interaksi berteman adalah melakukan bullying verbal dan non verbal terhadap teman; memalak teman; agresif; pemilih teman; ditolak teman; bergaul dengan kelompoknya sendiri; suka bertengkar dan membuat keributan; dan suka mengejek.

\section{Analisis}

Hasil dari FGD terhadap 15 guru sekolah dasar di Kota Yogyakarta menemukan berbagai aspek dari keterampilan sosial berbasis diversity awareness. Data tersebut kemudian dianalisis untuk dikonstruksi menjadi skala. Berdasarkan hasil FGD yang menggunakan panduan berupa konsep keterampilan sosial, muncul tujuh aspek. Aspek-aspek tersebut dari yang muncul paling banyak sampai yang paling sedikit adalah kemampuan empati (32,4\%), komunikasi dan interaksi sosial $(28,9 \%)$, mengendalikan agresi $(10,8 \%)$, sikap terbuka $(8,8 \%)$, perilaku membantu $(8,3 \%)$, kemampuan memahami diri $(6,9 \%)$, dan perilaku mau belajar $(3,9 \%)$. Setelah itu skala dikonstruksi dengan memunculkan banyaknya item berdasarkan presentase kemunculan masing-masing aspek. Konstruk skala terdiri dari kemampuan empati 15 item, komunikasi dan interaksi sosial 13 item, mengendalikan agresi 5 item, sikap terbuka 4 item, perilaku membantu 4 item, memahami diri 3 item, dan perilaku belajar 2 item. Tabel 1 menunjukkan frekuensi dan persentase kemunculan dari masingmasing aspek tersebut serta jumlah item masing-masing. 
Tabel 3. Aspek dan Sebaran Item pada Skala Keterampilan Sosial

\begin{tabular}{llll}
\hline \multicolumn{1}{c}{ Kata Kunci } & $\begin{array}{c}\text { frekuensi } \\
\text { jawaban } \\
\text { responden (n) }\end{array}$ & $\begin{array}{c}\text { frekuensi } \\
\text { jawaban } \\
\text { responden (\%) }\end{array}$ & $\begin{array}{c}\text { Jumlah } \\
\text { item }\end{array}$ \\
\hline kemampuan empati & 66 & 32,4 & 15 \\
komunikasi dan interaksi sosial & 59 & 28,9 & 13 \\
mengendalikan agresi & 22 & 10,8 & 5 \\
sikap terbuka & 18 & 8,8 & 4 \\
perilaku membantu & 17 & 8,3 & 4 \\
memahami diri & 14 & 6,9 & 3 \\
perilaku mau belajar & 8 & 3,9 & 46 \\
TOTAL ITEM PADA SKALA & & & \\
\hline
\end{tabular}

Langkah berikutnya adalah memilah indikator-indikator dari masing-masing aspek yang muncul. Indikator diperoleh dari ungkapan-ungkapan subjek yang muncul saat FGD. Indikator ini yang kemudian akan menjadi item-item pada skala. Meskipun alat ukur keterampilan sosial ini berdasarkan diversity awareness, namun menurut hasil FGD kondisi beragam yang paling berimplikasi terhadap keterampilan sosial adalah keragaman kemampuan siswa atau keberadaan berbagai tipe siswa berkebutuhan khusus di sekolah. Hal ini tampak pada indikatorindikator yang disampaikan subjek. Tabel 2 berikut memperlihatkan indikator dari masing-masing aspek beserta jumlah itemnya sesuai dengan proporsi persentase kemunculan saat FGD.

\section{Tabel 4. Indikator Skala Keterampilan Sosial}

\begin{tabular}{llc}
\hline Aspek & \multicolumn{1}{c}{ Indikator } & Item \\
\hline Kemampuan & 1. Menghargai perbedaan fisik antar teman, & 15 \\
2. Menghargai perbedaan non fisik antar teman, & \\
& 3. Menghargai kekurangan teman, \\
& 4. Menghargai kelebihan teman, \\
& 5. Menerima perbedaan teman yang tidak berkebutuhan \\
& khusus, \\
& 6. Menerima perbedaan teman berkebutuhan khusus, \\
7. Bersikap toleran, & \\
8. Melindungi teman berkebutuhan khusus, \\
9. Menyesal apabila berbuat salah, \\
10. Memperhatikan teman, \\
11. Memberi dukungan pada teman berkebutuhan khusus, \\
12. Memberi kesempatan pada teman berkebutuhan khusus, \\
13. Memberi tanggapan yang baik, \\
14. Tidak mengganggu teman.
\end{tabular}




\begin{tabular}{|c|c|c|}
\hline $\begin{array}{l}\text { Komunikasi } \\
\text { dan interaksi } \\
\text { sosial }\end{array}$ & $\begin{array}{l}\text { 1. Bekerjasama dengan semua teman } \\
\text { 2. Berkerjasama dengan teman ABK } \\
\text { 3. Bekerjasama untuk hal yang positif } \\
\text { 4. Berinteraksi dengan teman } \\
\text { 5. Tidak menghindari guru atau orang dewasa lain } \\
\text { 6. Terlibat dalam kegiatan berkelompok } \\
\text { 7. Mau berkomunikasi timbal balik secara verbal dan } \\
\text { atau non verbal } \\
\text { 8. Mau memulai komunikasi dengan teman } \\
\text { 9. Sopan dalam berbicara dan atau berperilaku } \\
\text { 10. Tidak memilih-milih teman } \\
\text { 11. Memulai menyapa } \\
\text { 12. Mudah akrab dan memperhatikan guru dan teman } \\
\text { 13. Diterima oleh lingkungan (teman, sekolah) }\end{array}$ & 13 \\
\hline $\begin{array}{l}\text { Mengendalikan } \\
\text { agresi }\end{array}$ & $\begin{array}{l}\text { 1. Tidak mengintimidasi teman } \\
\text { 2. Tidak membullyi teman berkebutuhan khusus } \\
\text { 3. Tidak membullyi teman pada umumnya } \\
\text { 4. Menahan untuk tidak berkata kasar atau jorok } \\
\text { 5. Mengendalikan diri dari perilaku kasar atau tidak baik }\end{array}$ & 5 \\
\hline Sikap terbuka & $\begin{array}{l}\text { 1. Berperilaku jujur atau tidak berbohong } \\
\text { 2. Percaya diri } \\
\text { 3. Memiliki kemampuan untuk jadi pemimpin } \\
\text { 4. Bersikap terbuka dan mudah menyesuaikan diri }\end{array}$ & 4 \\
\hline $\begin{array}{l}\text { Perilaku } \\
\text { membantu }\end{array}$ & $\begin{array}{l}\text { 1. Berinisiatif menawarkan bantuan } \\
\text { 2. Mau membantu teman berkebutuhan khusus } \\
\text { 3. Mau membantu teman lainnya } \\
\text { 4. Mau berbagi }\end{array}$ & 4 \\
\hline $\begin{array}{l}\text { Memahami } \\
\text { diri }\end{array}$ & $\begin{array}{l}\text { 1. Menyadari kekurangan dan kelebihan dirinya } \\
\text { 2. Mau mengekspresikan kemampuannya } \\
\text { 3. Mau menyesuaikan diri dengan lingkungannya }\end{array}$ & 3 \\
\hline $\begin{array}{l}\text { Perilaku mau } \\
\text { belajar }\end{array}$ & $\begin{array}{l}\text { 1. Bersemangat dan terlihat senang belajar dan sekolah } \\
\text { 2. Mau terlibat dalam kegiatan sekolah }\end{array}$ & 2 \\
\hline
\end{tabular}

Data FGD juga berhasil merumuskan pengertian keterampilan sosial siswa SD berdasarkan diversity awareness. Definisi tersebut adalah kemampuan menerima situasi sosial dan berperilaku verbal maupun non verbal untuk berinteraksi dengan orang lain sesuai dengan norma dan aturan yang berlaku.

\section{Pembahasan}

Analisis data hasil penelitian berhasil merumuskan definisi keterampilan sosial siswa SD berdasarkan diversity awareness. Definisi tersebut adalah kemampuan menerima situasi sosial dan kemampuan berperilaku verbal maupun non verbal untuk berinteraksi dengan orang lain sesuai dengan norma dan aturan yang berlaku. Definisi tersebut sama dengan pengertian keterampilan sosial menurut Gresham (Shepherd, 2010:67) dan Maag (2006:10) yakni perilaku yang membantu seseorang untuk berhubungan sosial dengan lingkungan.

Definisi yang dirumuskan dari hasil FGD lebih rinci karena menyebut secara eksplisit kemampuan verbal dan non verbal. Hal ini menunjukkan situasi keberagaman yang seringkali dihadapi siswa SD di sekolah inklusif. Selalu ada kemungkinan adanya siswa dengan karakteristik khusus berupa hambatan wicara dan komunikasi, sehingga perilaku yang menunjukkan keterampilan sosial 
tidak harus diwujudkan dalam perilaku verbal. Dasar keberagaman juga tampak pada definisi hasil penelitian, yakni menerima situasi sosial yang bisa dipastikan bervariasi. Brown \& Brown (2004:89) menyatakan bahwa Diversity awareness adalah kesadaran akan adanya keberagaman di sekitar yang aspeknya adalah pemahaman mengenai keberagaman tersebut, sikap menghargai, pengenalan akan nilai-nilai yang berbeda, dan pengetahuan mengenai dampak keberagaman.

Aspek-aspek keterampilan sosial yang muncul dari hasil FGD adalah kemampuan empati $(32,4 \%)$, komunikasi dan interaksi sosial (28,9\%), mengendalikan agresi $(10,8 \%)$, sikap terbuka $(8,8 \%)$, perilaku membantu $(8,3 \%)$, kemampuan memahami diri $(6,9 \%)$, dan perilaku mau belajar $(3,9 \%)$. Indikator yang muncul terbanyak adalah dari aspek kemampuan empati. Pada guru berpendapat bahwa pada situasi beragam, kemampuan empati sangat dibutuhkan untuk mendasari berkembangnya aspek lain dari keterampilan sosial. Setelah itu, persentase terbesar berikutnya adalah kemampuan komunikasi dan interaksi sosial serta kemampuan mengendalikan agresi. Urutan terbanyak tersebut sangat sesuai dengan Walker \& Mc.Connell (Merrell, 2001:17) yang menyebutkan bahwa kemampuan empati merupakan salah satu aspek keterampilan sosial yang disarankan oleh guru selain dari kontak dan komunikasi, kompromi dan kerjasama, dan mengatasi masalah tanpa agresivitas. Karten (2008:45) menambahkan bahwa dalam konteks diversity, hubungan sosial dilandaskan pada sikap akomodatif terhadap perbedaan. Sikap terbuka yang meliputi indikator berperilaku jujur, terbuka, percaya diri, dan memiliki kemampuan menjadi pemimpin sesuai dengan Walker \& Mc.Connell (Merrell, 2001:18) yang merumuskan perilakuperilaku tersebut sebagai perilaku sosial yang mendukung interaksi berteman. Kemudian perilaku mau belajar juga dirumuskan Walker \& Mc.Connell sebagai perilaku yang mencerminkan perilaku penyesuaian pembelajaran yang merupakan aspek dari keterampilan sosial siswa.

Kontruksi alat ukur keterampilan sosial berdasarkan diversity awareness dibutuhkan untuk mengetahui keterampilan sosial siswa, terutama di SD inklusif. Mengetahui tingkat keterampilan sosial siswa diperlukan untuk menyusun mendukung pengembangan keterampilan sosial siswa. Pengembangan tersebut penting untuk mendukung keberhasilan penyelenggaraan pendidikan pada setting keberagaman yang sekarang ini terwujud di sekolah inklusif. Di sekolah inklusif, diversity awareness tampak pada sikap akomodatif dan mutualisme seluruh personel sekolah terhadap kemungkinan adanya perbedaan di antara mereka (Karten, 2008:60).

\section{PENUTUP}

Berdasarkan hasil penelitian, kesimpulan yang diperoleh dari penelitian ini adalah : 1) Aspek keterampilan sosial berdasarkan diversity awareness yang berhasil dirumuskan tujuh (7) aspek, meliputi kemampuan empati $(32,4 \%)$, komunikasi dan interaksi sosial $(28,9 \%)$, mengendalikan agresi (10,8\%), sikap terbuka $(8,8 \%)$, perilaku membantu $(8,3 \%)$, kemampuan memahami diri $(6,9 \%)$, dan perilaku mau belajar $(3,9 \%) .2)$ Rancangan instrumen pengukuran skala keterampilan sosial siswa SD inklusif berbasis diversity awareness terdiri dari indikator-indikator yang ditetapkan berdasarkan proporsi persentase kemunculan masing-masing aspek. Aspek kemampuan empati memiliki 15 indikator, komunikasi dan interaksi sosial 13 indikator, mengendalikan agresi 5 indikator, sikap terbuka 4 indikator, perilaku membantu 4 indikator, memahami diri 3 indikator, dan perilaku mau belajar 2 indikator. Total indikator berjumlah 46 yang menjadi item pada alat ukur yang dihasilkan. 


\section{Saran}

Saran dari hasil penelitian ini adalah: 1) Diperlukan penelitian lanjutan untuk menguji rancangan skala pengukur keterampilan sosial berdasarkan prinsip psikometri sehingga akan berhasil memeroleh skala yang valid dan reliabel. 2) Skala atau alat ukur keterampilan sosial yang sudah jadi dapat digunakan di sekolah inklusi sebagai instrumen penelitian guru dan instrumen pengukur perilaku untuk menjadi tolak ukur rancangan dan keberhasilan program pengembangan keterampilan sosial siswa.

\section{DAFTAR PUSTAKA}

Brown, I. \& Brown, R.I. (2004). Quality of Life and Disability an Approach for Community Practitioners. London: Jessica Kingsley Publishers.

Dereli, E. (2009). Examining the Permanence of the Effect of a Social Skills Training Program for the Acquisition of Social Problemsolving Skills. Social Behavior and Personality, 37 (10), p.1419-1428.

Favazza, P. dkk. (2000). Measuring and Promoting Acceptance of Young Children with Disabilities. Exeptional Children, Summer 2000 (66), p.491.

Karten, T.J. (2008). Embracing Disabilities in the Classroom, Strategies to Maximize Students' Assets. California: Corwin Press.

Kluth, P. (2003) Access to Academics for All Students: Critical Approaches to Inclusive Curriculum, Instructionand Policy. New Jersey: Lawrence Erlbaum Associates,

Maag, J. W. (2006). Social Skill Training for Students with Emotional ang Behavioral Disorders: A Review of Reviews. Behavioral Disorders, 32 (1), p.5-17.

Mahabbati, A. (2012). Program Dukungan Perilaku Positif untuk Meningkatkan Keterampilan Sosial Anak dengan Conduct Disorder pada Seting Sekolah. Tesis.
Magister Sains Psikologi Fakultas Psikologi UGM. Tidak diterbitkan. Marlina. (2006) Tingkat Penerimaan Teman Sebaya pada Siswa Berkesulitan Belajar di Sekolah Inklusi. JPK Vol.2 No. 1 Mei. 2006, p.30-39.

Mazurik-Charles, R., \& Stefanou, C. (2010). Using Paraprofesionals to Teach Social Skills to Children with Autism Spectrum Disorders in the General Education Classroom. Journal of Instructional Psychology, 37 (2), p.161-169.

Merrell, K. W. (2001). Assessment of Children's Social Skills: Recent Developments, Best Practices, and New Directions. Exceptionality, 9 (1\&2), p.3-18.

Purwandari, Pujaningsih, \& Mahabbati, A. (2014). Program Positive Behavior Support untuk Meningkatkan Keterampilan Sosial Siswa SD. Laporan Penelitian Hibah Bersaing. Fakultas Ilmu Pendidikan UNY. Tidak diterbitkan.

Saifuddin Azwar. (2008). Penyusunan Skala Psikologi. Yogyakarta:

Pustaka Pelajar.

Samanci, O. (2010). Teacher Views on Social Skills Development in Primary School Students. Education, 131 (1), p.147-157.

Shepherd, T. (2010). Working with Students with Emotional and Behavior Disorders. New Jersey: Pearson Education Inc.

Swift, M. C., Roeger, L., Walmsley, C., Howard, S., Furber, G., \& Allison, S. (2009). Rural Children Referred for Conduct Problems: Evaluation of a Collaborative Program. Australian Journal of Primary Health, 15, 335-340.

Vaidya, W \& Zaslavsky. (2000). Inclusion Classrooms: Knowledge versus Pedagogy. Proquest Education Journals, 121, 1, p.14. 